\title{
Simple method of diagnostic screening for amyloidosis
}

\author{
B. STENKVIST, P. WESTERMARK, AND L. WIBELL \\ From the Departments of Clinical Cytology, Pathology, and Internal Medicine, University Hospital, \\ University of Uppsala, Uppsala, Sweden
}

The diagnosis of amyloid disease usually rests on attempts to obtain adequate specimens for the study of histological sections from the rectal mucosa or internal organs. Such procedures are not suitable for the screening of large groups of patients. Fineneedle biopsy of the subcutaneous fat (Westermark and Stenkvist, 1971) would, however, be simple and safe enough for use in clinical practice or in surveys of patient populations. A pilot study was therefore performed in a group of subjects liable to include a few cases of hitherto undetected secondary amyloidosis.

\section{Material and methods}

A series of 47 patients admitted to a hospital with rheumatic diseases for active treatment or rehabilitation was selected on the basis of a clinical picture resembling rheumatoid arthritis. In 36 of them the rheumatoid factor test (Latex-RF reagent, Behringwerke) was positive. Five had active arthritis of only a few years' duration but the others suffered from long-standing and disabling joint disease. None of the patients was known to have amyloidosis. In each patient the aspiration of subcutaneous fat was performed on five different locations from the xiphoid process to the symphysis. After gentle distribution on a glass slide the aspirated material was allowed to dry in air and was then stained with congo red by the method of

Accepted for publication May 15, 1973.
Puchtler, Sweat, and Levine (1962). The biopsy procedure added less than 5 minutes to the consultation time. The techniques of aspiration, staining, and examination have previously been described in detail (Westermark and Stenkvist, 1971, 1973). The procedure includes the use of true green birefringence under polarization.

\section{Results}

In two out of the 47 patients, small deposits of amyloid were found in the smears with fragments of adipose tissue. Both these subjects had a positive test for rheumatoid factor. Surgical rectal biopsy was subsequently performed and was confirmatory in both patients.

\section{Discussion}

In the present study no false positive results were obtained. In previous reports (Westermark and Stenkvist, 1971, 1973) eight out of nine positive smears were also confirmed by rectal biopsy or autopsy, and the remaining patient, not further investigated, had myelomatosis and renal insufficiency (Table). In this previous study a strong clinical suspicion of amyloidosis initiated further histological studies in eight patients with negative needle aspiration biopsy and none of the smears turned out to be

Table Results of fine-needle biopsy of subcutaneous abdominal fat in diagnosis of amyloidosis

\begin{tabular}{|c|c|c|c|c|c|c|}
\hline \multirow[t]{3}{*}{ Patient group } & \multirow{3}{*}{$\begin{array}{l}\text { Aspiration } \\
\text { biopsy } \\
\text { findings }\end{array}$} & \multicolumn{5}{|c|}{ Number of patients } \\
\hline & & \multicolumn{2}{|c|}{ With amyloidosis } & \multicolumn{2}{|c|}{ Without amyloidosis } & \multirow[t]{2}{*}{ Tota } \\
\hline & & $\begin{array}{l}\text { Rectal } \\
\text { biopsy or } \\
\text { autopsy }\end{array}$ & $\begin{array}{l}\text { Rectal } \\
\text { biopsy not } \\
\text { performed }\end{array}$ & $\begin{array}{l}\text { Rectal } \\
\text { biopsy or } \\
\text { autopsy }\end{array}$ & $\begin{array}{l}\text { Rectal } \\
\text { biopsy not } \\
\text { performed }\end{array}$ & \\
\hline Present series with rheumatoid arthritis & $\begin{array}{l}\text { Positive } \\
\text { Negative }\end{array}$ & $\begin{array}{l}2 \\
0\end{array}$ & $\begin{array}{l}0 \\
0\end{array}$ & $\begin{array}{l}0 \\
0\end{array}$ & $\begin{array}{r}0 \\
45\end{array}$ & $\begin{array}{r}2 \\
45\end{array}$ \\
\hline Previous cases & $\begin{array}{l}\text { Positive } \\
\text { Negative }\end{array}$ & $\begin{array}{l}8 \\
0\end{array}$ & $1^{*}$ & $\begin{array}{l}0 \\
7\end{array}$ & $\begin{array}{r}0 \\
12\end{array}$ & $\begin{array}{r}9 \\
19\end{array}$ \\
\hline
\end{tabular}

* Myelomatosis and renal insufficiency. 
falsely negative. Our present experience thus suggests that the fine-needle aspiration technique although simple is a reliable method for the diagnosis of secondary amyloidosis. It should be useful for the investigation of fairly large groups of patients and would facilitate prospective studies of the disease. In the present pilot series two positive cases out of 47 corresponds to an incidence of 4.3 per cent. which is similar to other findings of secondary amyloidosis in patients with rheumatoid arthritis (Arapakis and Tribe, 1963; Bywaters, Ansell, and Smith, 1968; Fearnley and Lackner, 1955).

\section{Summary}

In a pilot study of 47 patients with rheumatoid joint disease fine-needle aspiration of subcutaneous fat was used for the detection of secondary amyloidosis. Two patients had positive smears and the diagnosis was confirmed by rectal biopsies. The method is very simple and appears to be suitable for screening purposes.

Our thanks are due to the head physician at Strängnäs Hospital for Rheumatic Diseases, Dr. Lars Forsman, and his staff, who kindly put their patients and equipment at our disposal.

\section{References}

Arapakis, G., AND Tribe, C. R. (1963) Ann. rheum. Dis., 22, 256 (Amyloidosis in rheumatoid arthritis investigated by means of rectal biopsy)

Bywaters, E. G. L., ANSEll, B. M., AND Smith, M. E. (1968) 'Amyloidosis in rheumatoid arthritis', in 'Amyloidosis', ed. E. Mandema, L. Ruinen, J. H. Scholten, and A. S. Cohen, p. 391. Excerpta Medica Foundation, Amsterdam

FeARNLEY, G. R., AND LACKNER, R. (1955) Brit. med.J., 1, 1129 (Amyloidosis in rheumatoid arthritis, and significance of 'unexplained' albuminuria)

Puchtler, H., Sweat, F., AND Levine, M. (1962) J. Histochem. Cytochem., 10, 355 (On the binding of Congo red by amyloid)

Westermark, P., AND Stenkvist, B. (1971) Acta med. scand., 190, 453 (Diagnosis of secondary generalized amyloidosis by fine needle biopsy of the skin)

$$
\text { (1973) Arch. intern. Med., 132, } 522 \text { (A new method for the diagnosis of systemic amyloidosis) }
$$

